\title{
The Next Therapeutic Challenge in HIV: Polypharmacy
}

\author{
E. Jennifer Edelman · Kirsha S. Gordon • \\ Janis Glover • Ian R. McNicholl • David A. Fiellin • \\ Amy C. Justice
}

Published online: 6 June 2013

(C) Springer International Publishing Switzerland 2013

\begin{abstract}
With the adoption of combination antiretroviral therapy (ART), most HIV-infected individuals in care are on five or more medications and at risk of harm from polypharmacy, a risk that likely increases with number of medications, age, and physiologic frailty. Established harms of polypharmacy include decreased medication adherence and increased serious adverse drug events, including organ system injury, hospitalization, geriatric syndromes (falls, fractures, and cognitive decline) and mortality. The literature on polypharmacy among those with HIV infection is limited, and the literature on polypharmacy among non-HIV patients requires adaptation to the special issues facing those on chronic ART. First, those aging with HIV infection often initiate ART in their 3rd or 4th decade of life and are expected to remain on ART for the rest of their lives. Second, those with HIV may be at
\end{abstract}

E. J. Edelman

Yale University School of Medicine, New Haven, CT, USA

e-mail: ejennifer.edelman@yale.edu

K. S. Gordon

VA Connecticut Healthcare System, West Haven, CT, USA

J. Glover

Yale University, New Haven, CT, USA

I. R. McNicholl

UCSF Positive Health Program at San Francisco General

Hospital, University of California, San Francisco, CA, USA

D. A. Fiellin - A. C. Justice

Yale University Schools of Medicine and Public Health,

New Haven, CT, USA

A. C. Justice $(\square)$

VA Connecticut Healthcare System, 950 Campbell Avenue,

West Haven, CT 06516, USA

e-mail: Amy.Justice2@va.gov higher risk for age-associated comorbid disease, further increasing their risk of polypharmacy. Third, those with HIV may have an enhanced susceptibility to harm from polypharmacy due to decreased organ system reserve, chronic inflammation, and ongoing immune dysfunction. Finally, because ART is life-extending, nonadherence to ART is particularly concerning. After reviewing the relevant literature, we propose an adapted framework with which to address polypharmacy among those on lifelong ART and suggest areas for future work.

\section{The Drug Treatment Paradox: What is Different Among those Aging with HIV?}

Physicians and their aging patients face a drug treatment paradox [1]. Aging individuals inevitably develop multiple health conditions (multimorbidity), and disease-specific guidelines recommend one or more additional medications for each diagnosis [2-6]. Evidence supporting these recommendations is of variable strength and was obtained from younger patients free of competing health conditions and less susceptible to medication toxicity $[4,5]$. Conversely, older multimorbid patients may be more likely to benefit from certain organ-sparing treatments.

This paradox is particularly challenging for those aging with HIV infection, in whom the effectiveness of combination antiretroviral therapy (ART) is undeniable, guidelines recommend aggressive screening and treatment for a host of other health conditions (many of which may be more common among those with HIV), higher rates of organ system injury mean that they are particularly susceptible to treatment toxicity, and nonadherence to ART is much more concerning than nonadherence to most other medications. 
Polypharmacy, commonly defined as being on $\geq 5$ medications, is a growing problem in healthcare. It is the strongest predictor of serious adverse drug events (ADE) and drug-drug interactions [2, 7, 8]. While polypharmacy is a pressing issue in primary care, it may be an even greater concern among those aging with HIV infection, in whom combination ART has simultaneously increased survival [9-11] and the lifelong burden of medication [12, 13]. Several excellent reviews of the general issues of polypharmacy [14-16] have been published, and the Cochrane Collaboration recently conducted a structured review of interventions to improve the appropriate use of polypharmacy for older people [1]. General issues surrounding older, HIV-infected patients, focusing on those aged 50 and older, have also been delineated [17]. However, prior work has not addressed specific management issues surrounding polypharmacy among those aging with HIV infection.

Those aging with HIV have several somewhat unique management issues. First, polypharmacy is often "premature" in those with HIV. Since ART typically requires the use of at least three different antiretrovirals, many people with HIV experience polypharmacy the minute they start ART. For example, data from the North American AIDS Cohort Collaboration on Research and Design (NAACCORD) demonstrate that that while two-thirds of patients who are newly eligible for treatment are in their 30 s and 40s, $17 \%$ are younger than 30 [18]. Thus, their total time of exposure to polypharmacy is extended compared to the general population, which more typically begins lifelong therapy for chronic diseases such as hypertension, cardiovascular disease, or diabetes in their 5 th, 6 th, or 7 th decade. Second, those aging with HIV are at higher risk for many age-associated conditions that may be driven in part by HIV infection and ART toxicity (e.g., hyperlipidemia, atherosclerosis, and osteoporosis) [17, 1921]. Additionally, current Department of Health and Human Services (DHHS) guidelines recommend that primary care guidelines be applied equally to those aging with HIV [22]. Given the lower thresholds for the treatment of conditions such as hypertension, hyperlipidemia, and diabetes that have been adopted over the last decade, the application of these guidelines to those aging with HIV will almost inevitably lead to increasing levels of polypharmacy [23]. While evidence supporting ART for HIV infection is overwhelming, the strength of evidence for other routine screening and treatment practices is variable and based on studies in demographically and behaviorally distinct uninfected individuals.

Third, those with HIV infection may have an enhanced susceptibility to harm from polypharmacy due to decreased organ system reserve, chronic inflammation, and ongoing immune dysfunction [20, 21]. Due to the increased prevalence of both liver [24] and renal disease [25-27] among older, HIV-infected patients, they may have altered pharmacodynamics and be more vulnerable to injury from both commonly used non-HIV medications [28], as well as cART [29, 30]. Fourth, polypharmacy is associated with poorer adherence, so adding medication to address other problems may diminish the life-preserving effectiveness of ART. We consider these issues as we review the general and HIV-specific literature relevant to polypharmacy, and suggest how existing interventions might be adapted to those aging with HIV.

\section{Methods}

We performed a comprehensive review of the literature, searching the following databases for relevant studies: MEDLINE (OvidSP 1948 to September 2012); Embase (OvidSP 1974 to September 2012), and CENTRAL (Cochrane Library, September 2012). The search strategies used a combination of controlled vocabulary terms and text words to capture the concepts of polypharmacy and specific conditions/issues [drug interactions, medication errors, inappropriate prescribing, falls, hospitalization, adverse drug reaction, mortality, quality of life, organ injury (e.g., liver failure, renal insufficiency, etc.), and activities of daily living], and were limited to English language manuscripts and to subjects 45 years or older. We used this cutoff given our interest in focusing on older HIV-infected patients, commonly defined as 50 years and older [17]. The reference lists of included papers were hand-searched. Together, these papers provided the foundation for our discussion on polypharmacy. We complemented this with targeted searches that were performed as needed, including searches for studies focused on HIVinfected populations.

\section{What is Polypharmacy?}

A range of definitions have been applied to the term polypharmacy, including the use of at least one unnecessary medication and different thresholds for the number of medications in a patient's regimen [7, 8, 31]. There is a clear dose-response association with harms of polypharmacy, so that those who are on 5-6 medications are at lower risk than those on 7-8 or $>9$ medications [32-34]. Consistent with others [8, 35], we prefer to define polypharmacy specifically as the use of 5 or more medications in a medication regimen, since this threshold has been consistently associated with important negative health 
outcomes [36] and is supported by empiric work [37]. Specifically, Gnjidic and colleagues explored the best cutoff for defining polypharmacy based on associations with health outcomes among a community sample of older men. They found that the number of medications was 6.5 to identify risk of frailty, 5.5 for disability, 4.5 for mortality, and 4.5 for falls, supporting the use of 5 or more medications as a clinically meaningful definition of polypharmacy [37].

\section{How Common is the Problem of Polypharmacy in HIV?}

Polypharmacy among those in care for HIV infection is common. One study, which examined data from a Canadian cohort from 1990 to 2010, found that the total daily pill burden (TDPB) decreased over time; this was attributed to improvements in ART. Yet, in 2010, $22 \%$ of patients took 10 or more pills per day (mean TDPB $6.7 \pm 5.8), 51 \%$ of which were ART. Further, older patients (defined as older than 45 years old) took, on average, 3 pills more per day than younger patients (defined as 45 years old or younger) (7.6 vs. 4.7 pills), which was generally related to their greater need for nonART medications [13]. Similarly, recent data from the Swiss HIV Cohort demonstrate that among those 65 years and older, $14 \%$ received medications from 4 or more classes of non-HIV medications, where lipid-lowering agents were the most commonly prescribed non-ART medication [12]. These data are consistent with findings from the Veterans Aging Cohort Study (VACS), where the average number of daily long-term medications increased

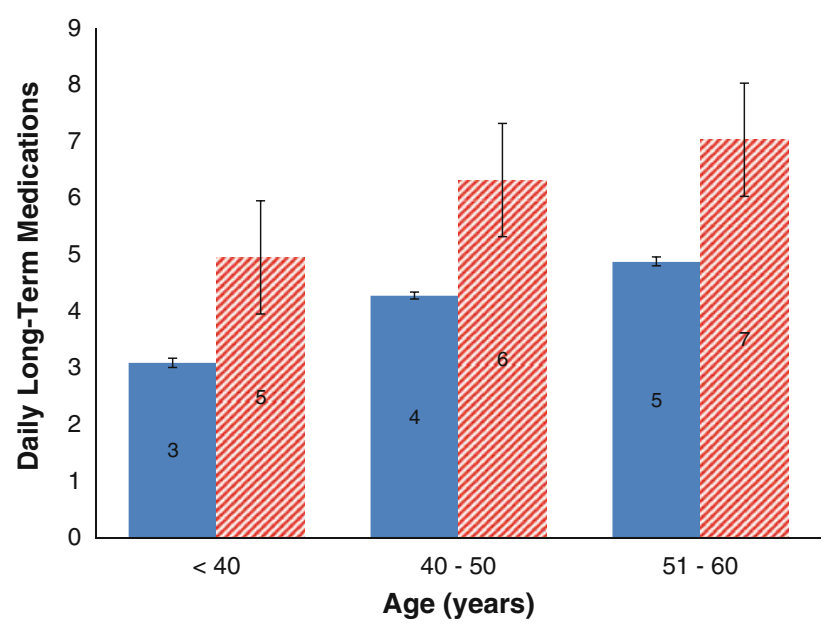

Uninfected, $n=47613$ ஜHIV-infected, $n=16324$

Fig. 1 Veterans Aging Cohort Study: median number of daily longterm medications by HIV status and age. Thin black bar indicates the corresponding $95 \%$ confidence interval with age (Fig. 1) (unpublished data). Further, among those 50 years and older, $55 \%$ were on 5 or more daily medications.

Because these studies report only prescription medication, they likely underestimate the prevalence of polypharmacy [13, 38-44]. Among all the medications that 104 HIV-infected patients interviewed in Ontario reported that they used, $18 \%$ were ART, $22 \%$ were non-ART prescriptions, $25 \%$ were over-the-counter, $22 \%$ were complementary and alternative, and $13 \%$ represented nonmedical use [39]. Of note, $17 \%$ of HIV-infected patients experience at least one or more ADE attributable to an over-the-counter medication [44]. Further, patient self-medication is common [2], especially among HIVinfected patients [39, 45, 46]. Even when excluding drugs used for nonmedical reasons, patients reported an average number of drugs of $14 \pm 8$, compared to $8 \pm 5$ documented in the medical chart [39]. A systematic review found that there is variability in whether patients report their use of complementary and alternative medicine to their health care providers, with rates ranging from 38 to $90 \%$ [45].

\section{What is the Most Important Treatment in HIV?}

Evidence for the efficacy of ART is overwhelming [9, 47]. While very effective, the use of ART in older HIV-infected patients may be associated with more toxicity than it is among younger individuals. First, there are limited data evaluating the safety and efficacy of ART in older populations and the impact of multiple medications. Randomized controlled trials generally include younger, healthier patients, excluding older patients with comorbidity [4850]. Despite their potential for altered efficacy, metabolism, ADE, and drug interactions in older patients, there is a paucity of data to inform the choice of antiretroviral agents in this population [17, 22, 51, 52]. This applies to recently approved medications as well [48-50].

Second, ADE are common with ART [53], and older patients are more likely to experience ADE, leading to treatment discontinuation [29]. Third, there are evolving data on the potential for harm with the long-term use of ART, with specific implications for older patients. For instance, there is evidence of increased risk of fracture [54] and renal disease [55-57] with the long-term use of tenofovir, a component of all of the currently recommended first-line regimens for treatment-naïve individuals [22]. While these data highlight the need for evidence assessing the long-term effects of ART and their safety in older populations, they do not undermine the fact that ART is highly effective at preventing AIDS-defining and nonAIDS-defining illnesses, improving quality of life, and 
prolonging survival. The question is not whether or not older individuals should be treated with ART, but which antiretrovirals should be selected and how commonly should they be monitored for toxicity.

\section{Polypharmacy and Harms}

\subsection{Nonadherence}

Polypharmacy is strongly associated with nonadherence in the general population [7, 58, 59]. Marcum and Gellad propose that, among older patients, this may be related to a dynamic process involving patient, health system, and provider factors. A recent systematic review found that nonadherence was associated with polypharmacy when focusing on the results of higher-quality studies [58, 59]. Nonadherence to ART is especially concerning, since it is associated with increased risk of hospitalization and mortality $[60,61]$.

Nevertheless, the effects of polypharmacy on ART and non-ART adherence are only beginning to be examined. An analysis of healthcare and pharmacy claims data including 3,057 patients found a relationship between increasing number of comorbidities and discontinuation of ART. Patients with 1, 2, and 3 or more comorbidities had a $6 \%(p=0.528), 28 \%(p=0.014)$, and $31 \%(p=0.02)$, respectively, higher risk of ART discontinuation compared with patients with no comorbidities [62]. While multiple factors may be at play, polypharmacy may contribute to these findings.

Notably, older HIV-infected patients are at increased risk for neurocognitive dysfunction, substance-use disorders, food insecurity, and limited social support compared with older uninfected patients [17, 19, 63-67]; these factors negatively impact adherence $[40,61,68,69]$. Whether these relationships are exacerbated by polypharmacy and their differential effects on ART and non-ART adherence remains to be determined.

\subsection{Adverse Drug Events}

While yet to be studied among those aging with HIV, there is strong evidence that polypharmacy increases the risk of ADE in the general population. A prospective study of individuals receiving outpatient care and newly initiating a medication found that the number of medications that a patient took was the only variable associated with the occurrence of an $\operatorname{ADE}(p<0.001)$ [33]. Moreover, with each additional medication, the mean number of ADE per patient increased by $10 \%$ [33]. While this study included a range of severity of ADE, these findings are consistent with studies that have assessed serious events. After adjusting for demographics, health status, and access-to-care factors, number of medications was found to be the only factor associated with ADE-related hospitalization. Risk increased with increasing threshold for number of medications: adjusted odds ratios [AOR] for 5-8 and $\geq 9$ medications were $2.85[1.03,7.85]$ and $3.90[1.43,10.61]$, respectively [35].

\subsection{Geriatric Syndromes: Falls, Fractures, and Dementia}

Geriatric syndromes including falls, fragility fractures, and dementia are more likely in the setting of polypharmacy and increasingly relevant to HIV care as patients age in the era of combination ART [7]. While specific classes of medications, including antidepressants, analgesics, benzodiazepines, and antihypertensives, have been associated with increased risk of falling [70], polypharmacy is independently associated with falls and fallrelated injuries among the general population [71, 72]. Taken together, polypharmacy is one of the strongest predictors of fall risk [73]. Based on the results of 10 studies, a meta-analysis found that, for each additional medication, there was a $5 \%$ increase in fall risk $(\mathrm{AOR}=1.05[95 \% \mathrm{CI} 1.01,1.09])$ among communitydwelling older uninfected adults [74].

Further, even more than decreased bone mineral density, falls are the major cause of fragility fractures [75]. Results from one cohort study of HIV-infected patients with a median age of 36 years found that, among patients who experienced a fracture, $81 \%$ of them sustained a fall as an immediate cause of the fracture [76]. Since low bone mineral density [76-78] means that HIV-infected patients are at increased susceptibility for fragility fractures, falls are of particular concern in this population. A study of 359 HIV-infected patients aged 45 to 65 years old on ART for at least 6 months with 1 undetectable plasma HIV-1 RNA viral load and no plasma HIV-1 RNA > 200 copies per milliliter in the prior 6 months demonstrated that each additional prescribed medication was associated with an incremental increase of 1.4 in the odds of falls $(95 \% \mathrm{CI}$ 1.3 to $1.6, p<0.001$ ) [79].

Risk of dementia and delirium is also increased in polypharmacy [7]. A prospective cohort study of 294 uninfected older persons found that individuals receiving 10 or more drugs, demonstrated decreased cognitive function over a 3-year time period compared to those on 0-5 medications [32]. HIV-associated neurocognitive disorder (HAND) can be an asymptomatic condition [80]. While the literature demonstrate that polypharmacy may contribute to symptomatic cognitive dysfunction [7, 32], patients with HAND may be more susceptible to these effects. 


\subsection{Mortality}

Of all the harms associated with polypharmacy, most notable is its association with mortality, even after adjustment for disease burden [34, 36, 81]. Based on a population-based study, Richardson and colleagues found that people aged 65 years and older in the general population with polypharmacy (defined as 5 or more medications) had a greater risk of mortality (adjusted HR 1.42 [95\% CI 1.28, 1.58] and 1.30 [95 \% CI 1.19, 1.41] for men and women, respectively) over the 18 -year follow-up period. These risks were greatest, however, in the short term (2 years) for both men (adjusted HR 1.94 [95 \% CI 1.59, 2.37]) and women (adjusted HR 1.88 [95 \% CI 1.56, 2.26]) [36].

A major methodologic challenge in determining whether polypharmacy has an independent association with mortality is its strong association with multimorbidity, which is, in itself, a major driver of mortality risk. One approach to this problem might be to adjust for overall risk of mortality using a validated risk index such as the VACS Index [82-85]. Nevertheless, while it remains to be determined whether polypharmacy is a risk factor for mortality or an additional consequence of multimorbidity among the general population and specifically HIV-infected patients, those with polypharmacy likely deserve special care.

\subsection{Over- and Underprescribing}

Polypharmacy is linked to poorer medication prescribing quality, including both over- (e.g., potentially inappropriate medications) and underprescribing. Here, potentially inappropriate medications refers to "medications [that] have no clear evidence-based indication, carry a substantially higher risk of adverse side-effects or [are] not costeffective (e.g. over prescribing)" [86]. Underprescribing refers to the lack of prescription of a potentially effective medication [87]. As the patient's problem list and number of medications expands, the provider's ability to pay attention to each condition and its treatment is reduced [6].

Similarly, increased number of medications is associated with an increased risk of exposure to harmful medications. An analysis of data from all VA outpatient clinics focusing on individuals older than 65 years old found that increased number of medications was associated with exposure to any high-risk medication (OR $=1.13[99 \%$ CI 1.12, 1.13]). Increased number of medications was also associated with exposure to specific high-risk medications, including antihistamines (OR $=1.12$ [99\% CI 1.11, 1.12]), opioids $(\mathrm{OR}=1.10$ [99 \% CI 1.09, 1.10]), psychotropics (OR $=1.12$ [99 \% CI 1.12, 1.13]), and skeletal muscle relaxants $(\mathrm{OR}=1.10$ [99 \% CI 1.10, 1.10]) [88]. These findings are consistent with other studies [89].
Literature on the impact of polypharmacy on the underuse of clinically indicated medications is mixed, as underuse may occur regardless of the number of prescribed medications, but it most commonly identifies the underuse of cardiovascular medications [2, 89].

To date, studies of prescribing practices to HIV-infected patients have focused on quality of HIV care [90, 91], but have not applied validated tools to assess for inappropriate medication use. However, there are growing data on underand overprescribing among HIV-infected populations. Errors involve the prescribing of both ART and ART/nonART combinations [92-94]. A review of claims data from 2005 , including over 12,000 patients, found that simvastatin was inappropriately co-prescribed with a protease inhibitor to $0.4 \%$ of patients, while atazanavir and tenofovir were prescribed together without the recommended ritonavir booster to $5.3 \%$ of patients [94]. In addition, data on the prescribing practices for individual classes of medications_-including opioid analgesics [95-99] — are mounting, with caution advised regarding prescribing practices [98].

As seen in HIV-uninfected patients [89], the underuse of medications to decrease risk of cardiovascular disease seems to occur regularly in HIV-infected patients. Freiberg and colleagues found that the prevalence of lipid-lowering medication among HIV-infected patients who met the National Cholesterol Education Program/Adult Treatment Panel III criteria for therapy was $39 \%$, compared with $62 \%$ for uninfected patients $(p<0.01)$. In multivariable analysis, HIV-infected patients were almost $60 \%$ less likely than uninfected patients to receive indicated lipidlowering therapy (adjusted OR $=0.43$ [95\% CI 0.28, 0.67]) [100]. Aspirin for primary prevention of cardiovascular disease is also underprescribed to HIV-infected patients; in one study, only one in five patients who qualified for aspirin received it [101].

\section{Factors Contributing to Polypharmacy's Harms}

\subsection{Pre-existing Organ System Injury}

The concept of physiologic frailty is important when considering risks from polypharmacy, and it is an established concept in geriatrics [17]. Those who have pre-existing physiologic injury are likely at increased risk of adverse effects of treatment. What is not well established is how to measure this concept. Since the VACS Index is predictive of all-cause mortality, MICU admission, hospitalization, fragility fractures, functional performance, and cognitive function, and is correlated with biomarkers of chronic inflammation, it may offer a means of summarizing physiologic frailty among those with HIV infection [82-85, 102-105]. 


\subsection{Drug-Drug Interactions}

The number of medicines prescribed predicts the number of drug interactions likely to occur [1, 106]. HIV-infected patients on ART are likely to be especially susceptible to drug-drug interactions when receiving multiple medications [40, 41, 43, 107]. Protease inhibitors, non-nucleoside reverse transcriptase inhibitors, the integrase inhibitor/ booster combination elvitegravir/cobicistat, and the CCR5 inhibitor maraviroc are all metabolized by the cytochrome P450 (CYP) system and may function as both CYP inhibitors and inducers, leading to complex and potentially poorly predictable drug-drug interactions [22, 108]. In addition, raltegravir is a substrate of uridine diphosphate glucuronosyltransferase A1, an enzyme involved in the conjugation of many medications - the understanding of which is still evolving [108]. Guidelines recommend avoiding the co-administration of a variety of medications in the setting of ART, such as combinations of simvastatin and protease inhibitors and proton pump inhibitors in the setting of atazanavir or rilpivirine [22].

Not surprisingly, HIV-infected patients-especially those who are older-are at high risk of drug-drug interactions. Data from the Swiss HIV Cohort found that older patients were more likely to receive at least one non-ART medication than younger patients are $(82 \%$ vs. $61 \%$, $p<0.001$ ), and they had more frequent potential drugdrug interactions $(51 \%$ vs. $35 \%, p<0.001)$ [43]. This extends to prescription medications, over-the-counter medications and herbal supplements [43, 44, 109]. Careful attention to such potential drug-drug interactions [22, 40] is necessary to minimize potential drug-drug interactions [108]. Useful resources for ARV-drug interaction data include the University of California HIV Insite website (http://hivinsite.ucsf.edu/) and the University of Toronto Immunodeficiency Clinic website (http://www.hivclinic. $\mathrm{ca} / \mathrm{main} / \mathrm{drugs}$ _home.html). Of note, current data on drugdrug interactions are generally based on healthy volunteers [108]; there is less knowledge of the implications for older, HIV-infected patients. Given the high prevalence of hepatitis $\mathrm{C}$ virus (HCV) coinfection and liver fibrosis among HIV-infected patients $[24,30,110]$ and the associated implications for the pharmacodynamics and safety of both ART and commonly used medications, providers should be especially vigilant in checking for drug-drug interactions among those aging with HIV.

\subsection{Substance Use}

Prolonged multisubstance use (including alcohol, tobacco, non-medical use of controlled medications, and non-prescription psychoactive drugs) is common among those aging with HIV [46, 111] and likely plays a "silent" role in adverse consequences of polypharmacy. Alcohol and drug use, including opioids, cocaine, and methamphetamines, have a major dose-response influence on medication adherence and interactions with commonly prescribed medications [68, 112-115]. Alcohol and tobacco can influence drug clearance and activity levels directly and through effects on liver and kidney function, with important clinical impacts [116-119]. Use of controlled medications other than how they were prescribed or solely for the effect they provide (non-medical use) can result in over-sedation, overdose and death [120-122]. Non-medical use of controlled medications, use of alcohol or illicit drugs can result in serious unanticipated interactions with prescribed drugs [123]. For instance, the metabolism of delta9-tetrahydrocannabinol, the active agent in marijuana-the most commonly used illicit drug in the United States-is thought to occur through CYP2C9, and is impacted by selective serotonin reuptake inhibitors and tricyclic antidepressants [123]. Cocaine is a vasoactive compound that can cause coronary ischemia.

\subsection{Co-formulation}

While co-formulated therapies can be beneficial for minimizing dosing errors and improving medication adherence through a reduced pill burden, caution should be exercised among older individuals. For example, tenofovir disoproxil fumarate has been coformulated with different antiretroviral agents, including emtricitabine as Truvada ${ }^{\circledR}$; emtricitabine and efavirenz as Atripla ${ }^{\circledR}$; emtricitabine and rilpivirine as Complera ${ }^{\circledR}$; and emtricitabine and elvitegravir/cobicistat as Stribild ${ }^{\mathrm{TM}}$. These co-formulated preparations can be problematic when one component is contraindicated. For instance, tenofovir requires dose adjustment in patients with renal insufficiency [22], which is often missed [124]. Co-formulation can also be a problem in pain medication in which acetaminophen is often co-formulated with opioid analgesics. This can lead to the inadvertent prescribing of liver toxic medication to those with documented liver injury [125].

\subsection{Silos of Care}

Continuity and integration of care has been identified as a protective factor for minimizing polypharmacy, and silos of care are a risk factor for polypharmacy [2]. Though less true among older patients, HIV-infected patients often have incomplete retention in care $[126,127]$, which may contribute to polypharmacy. In addition, patients may be co-managed by both HIV providers and generalists [128-130], which may contribute to their risk of polypharmacy and its consequences [131]. HIV-infected patients receiving specialty psychiatric or addiction 
treatment often need to see multiple providers. Hospitalization often interrupts care continuity and contributes to polypharmacy in the general population [2]. Hospitalization occurs more frequently among those with HIV [132], and represents a high-risk time for medication errors [133-135].

Another concern among those with HIV infection on ART is that many routine issues are more familiar in primary clinics but are likely strongly influenced by HIV and its treatment. Data from VACS found that providers in Infectious Disease Clinics were less comfortable with managing comorbid diseases such as diabetes and hypertension than physicians practicing in General Medicine Clinics [136]. Where care is best provided and how to ensure continuity remains a major problem, though multidisciplinary teambased approaches are likely to be essential $[137,138]$.

\section{Interventions to Promote Safe, Effective, Prioritized Prescribing}

The evidence base for interventions to mitigate harms and maximize benefit among those at risk from polypharmacy is limited. A recent systematic review by the Cochrane Collaboration to identify interventions to improve medication prescribing for older people found, based on the results of 10 studies, that "it is unclear if interventions to improve appropriate polypharmacy, such as pharmaceutical care, resulted in a clinically significant improvement; however, they appear beneficial in terms of reducing inappropriate prescribing and medication-related problems" [1].

While it is apparent that the optimal strategy for promoting safe prescribing is evolving, we draw from previously proposed frameworks and our own research and clinical experience to suggest an initial approach adapted to the special needs of those aging with HIV infection (Fig. 2). These recommendations are influenced by the criteria developed by Gallagher, Beers and others [139142], the conceptual framework proposed by Scott et al. [16], the Cochrane review [1], and work including the use of a Clinical Decision Support intervention [143], assessments of symptom burden [144], and considerations for applying clinical care guidelines [145], including cancer screening in HIV [146]. We note that these recommendations require time and effort and therefore encourage research on workload distribution, efficacy, implementation, and cost-benefit, given the fundamental value of medication safety. This represents a proposed framework that still requires further evaluation.

\subsection{Medication Reconciliation}

This is an essential but time-consuming step. List all medications, the level of adherence, and associated symptoms. Start with a complete dispensing history from the
Fig. 2 Optimizing medication prescribing. ART antiretroviral therapy, VACS Veterans Aging Cohort Study

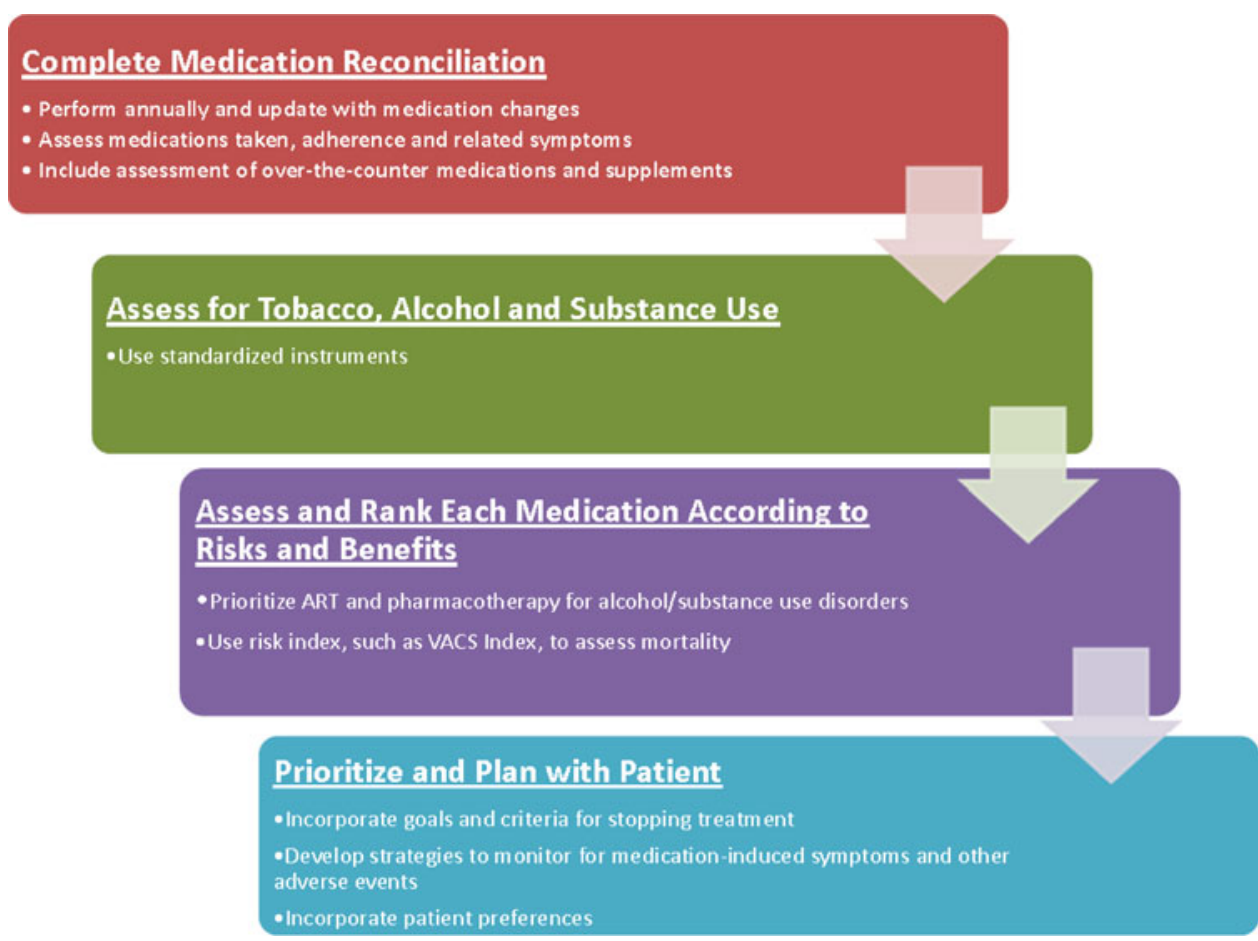


pharmacy and compare to the electronic medical record or paper chart and ask the patient to bring in all medications ("brown bag") [14]. It is essential that medication reconciliation includes questioning regarding supplements and over-the-counter medications [15] and an honest discussion with the patient about their level of adherence and sense of associated symptoms [144]. This process should be performed at least annually [14] and updated whenever medications are changed. All medications need to be verified for drug name, dose, frequency, and last fill date. Therapeutic duplication and continued indication should be evaluated prior to each renewal. If electronic fill/refill data is available, medication possession ratios can provide an unbiased estimate of adherence [147]. Those who live with the patient might also be asked to verify the medications, adherence, and associated symptoms. The process of medication reconciliation might be facilitated by a clinical pharmacist working in conjunction with the clinic or primary care provider. If possible, patients should utilize one pharmacy, as it will both facilitate medication reconciliation and help avoid risks from polypharmacy [17]. The efficiency of medication reconciliation may be improved through contact with the patient prior to the clinical encounter. For example, most primary care VA clinics ask the patient to review their list of current VA and non-VA medications prior to the clinical encounter and to discuss any discrepancies with their provider.

\subsection{Assess Substance Use}

Substance use, including alcohol and marijuana, is common among those with HIV infection, and influences risk of polypharmacy, likelihood of nonadherence, and susceptibility to adverse drug reactions (Table 1) [22, 114, $115,123,148-162]$. This assessment can be done concisely using standardized items, including the AUDIT-C [163] for alcohol, the 5A's for smoking [164], and the Short Inventory of Problems-Modified for Drug Use (SIP-DU) [165], the Drug Abuse Screening Test (DAST) [166], or a single question screen [167] for drug use. Drug use should include assessment of the non-medical use of controlled substances.

\subsection{Assess and Rank Each Medication According to Risks and Benefits}

Benefits and risks from each medication can be assessed based on standardized instruments, clinical judgment, and the general and HIV literature. Several groups have developed and piloted tools to identify under- and overprescribing for the general medical patient. The Medication Appropriateness Index relies on implicit criteria to identify the overuse of an individual medication based on the indication, effectiveness, dosage, implementation, duration, and cost [168]. Explicit criteria, generally based on expert consensus,

Table 1 Impact of substance use on ART

\begin{tabular}{|c|c|c|c|}
\hline Substance & Metabolism [123, 149, 151, 152] & $\begin{array}{l}\text { Clinical effect of substance-ART interactions } \\
{[22,123,151-153]}\end{array}$ & $\begin{array}{l}\text { Impact of } \\
\text { substance on } \\
\text { ART adherence }\end{array}$ \\
\hline Amphetamines & $\begin{array}{l}\text { Liver metabolism: aromatic hydroxylation; } \\
N \text {-dealkylation; deamination; CYP2D6, } \\
\text { CYP2B6, CYP1A2, CYP3A4 }\end{array}$ & $\begin{array}{l}\text { Protease inhibitors inhibit CYP3A4 and ritonavir, } \\
\text { nelfinavir, and efavirenz inhibit CYP2B6, potentially } \\
\text { leading to increased levels of amphetamines; } \\
\text { Fatal interaction has been reported with ritonavir }\end{array}$ & $\begin{array}{l}\text { Decreases }[115 \text {, } \\
162]\end{array}$ \\
\hline Cannabis & $\begin{array}{l}\text { CYP3A4, CYP2C9 substrate; smoking induces } \\
\text { CYP1A2 }\end{array}$ & $\begin{array}{l}\text { Protease inhibitors may increase risk of marijuana } \\
\text { toxicity; } \\
\text { No evidence of clinical impact on ART metabolism }\end{array}$ & $\begin{array}{l}\text { Decreases }[148, \\
150]\end{array}$ \\
\hline Cocaine & $\begin{array}{l}\text { Spontaneous hydrolysis; hepatic } \\
\text { cholinesterases; CYP 3A4 substrate; inhibits } \\
\text { CYP2D6 (strong); CYP3A4 (weak) } \\
\text { Increases P-glycoprotein levels }\end{array}$ & $\begin{array}{l}\text { Limited evidence, but could theoretically increase } \\
\text { excretion of ARTs transported by p-glycoprotein } \\
\text { leading to subtherapeutic levels (i.e., abacavir and } \\
\text { indinavir) }\end{array}$ & $\begin{array}{l}\text { Decreases }[114, \\
154-156,161, \\
162]\end{array}$ \\
\hline Ethanol & $\begin{array}{l}\text { Alcohol dehydrogenase, aldehyde } \\
\text { dehydrogenase }\end{array}$ & No clinically significant interactions with ARTs & $\begin{array}{l}\text { Decreases }[156, \\
157]\end{array}$ \\
\hline Opioids & $\begin{array}{l}\text { Hepatic esterases (heroin) } \\
\text { Glucuronidation (codeine, morphine) } \\
\text { CYP3A4, 2D6 (semisynthetic opioids, } \\
\text { i.e., hydrocodone, oxycodone) }\end{array}$ & $\begin{array}{l}\text { No known interactions between ART and heroin, } \\
\text { morphine and codeine } \\
\text { Oxycodone increased by CYP2D6 inhibitors (i.e., } \\
\text { ritonavir); hydrocodone effects are decreased as its } \\
\text { metabolite, hydromorphone, is more potent, potentially } \\
\text { resulting in withdrawal symptoms }\end{array}$ & $\begin{array}{l}\text { Decreases }[156, \\
158]\end{array}$ \\
\hline Tobacco & CYP 2A6, 1A2 & None reported & $\begin{array}{l}\text { Mixed data } \\
\quad[159,160]\end{array}$ \\
\hline
\end{tabular}

CYP cytochrome $\mathrm{P} 450$ 
have also been developed. The most commonly referenced explicit criteria are the BEERS Criteria. First published in 1991 [140] and regularly updated since then [169-171], the current BEERS Criteria include 53 specific medications/ medication classes to avoid in older patients. Only one of these sets of criteria addresses both over- and underprescribing: the Screening Tool of Older Persons' Potentially Inappropriate Prescriptions (STOPP) and Screening Tool to Alert Doctors to Right Treatment (START) criteria [139]. These include 65 indicators, which are mainly focused on drug-drug and drug-disease interactions and therapeutic duplication, and incorporate 22 evidence-based indicators of prescribing omissions.

While there are generally limited data demonstrating the use of these tools to improve clinical outcomes [86], current evidence suggests that the STOPP/START criteria are more sensitive than the BEERS criteria for identifying potentially inappropriate medications [172] and patients at risk for adverse drug events [173, 174], and that they may be used as an intervention to promote more appropriate prescribing [175]. Accordingly, the STOPP/START criteria have been endorsed over other tools $[172,176]$.

The adaptation of instruments such as the STOPP/ START criteria for HIV-infected patients will require additional investigation. For example, the START criteria recommend statin initiation under the following circumstances: (1) diabetes mellitus if one or more co-existing major cardiovascular risk factor is present; and (2) a documented history of coronary, cerebral, or peripheral vascular disease, where the patient's functional status remains independent for activities of daily living and life expectancy is $>5$ years, with the specification that simvastatin $40 \mathrm{mg}$ is typically the treatment of choice and that dose and choice should no longer be based on a target cholesterol except in diabetes [177]. Since HIV-infected patients have an increased risk of cardiovascular disease [178], and statins may have additional benefits in HIV-infected populations through their impact on inflammation [179], there may be expanded indications for statin therapy among HIV-infected patients. However, such recommendations need to balance the risks of polypharmacy [94], and should be tailored to minimize drug-drug interactions and optimize effectiveness [180]. Specifically, simvastatin and lovastatin are not recommended for those on protease inhibitors [22].

In addition, while the STOPP criteria indicate that longterm opiates should be stopped in those with recurrent falls and those with dementia unless indicated for palliative care or management of moderate-to-severe chronic pain syndrome, there may be additional indications for altering prescribing for HIV-infected patients. The potential benefits from pain relief should be weighed against the risk of developing opioid abuse and dependence [181-184], as well as other opioid side effects, including the potential for impaired immune function [185], system-level toxicities [186, 187] and interactions with medications, including ART [149, 151].

Risk can be assessed based on past medical history of ADEs, substance use, number of medications, and overall burden of disease. Given their role in drug metabolism and the high prevalence of disease in HIV-infected patients, liver, kidney, and bone marrow function should be carefully assessed with validated measures, such as those included in the VACS Index (http://vacs.med.yale.edu). Initially developed for HIV-infected patients, the VACS Index combines age with routinely ordered labs (HIV-1 RNA viral load, CD4 count, hemoglobin, platelets, aspartate and alanine transaminase, creatinine, and HCV serology) to predict all-cause mortality. In addition to mortality, the VACS Index predicts hospitalization and intensive care unit admission, and is correlated with functional performance, fragility fractures, and quality of life $[19,20,82$, $83,102,104,105,188,189]$. The VACS Index is also sensitive to changes in ART [85]. Patients at a higher risk of all-cause mortality based upon the VACS Index are likely at a greater risk of ADE due to their decreased organ system reserve and heightened risk of both short- and longterm mortality. While it holds promise as a potentially effective tool for guiding clinical decisions, randomized controlled trials are needed to evaluate whether the VACS Index prevents inappropriate prescribing.

\subsection{Prioritize and Plan with the Patient}

Prioritized ranking of medications should be informed by patient preferences including disease-specific benefit harm thresholds and the relative utility of individual drugs. ART will typically be ranked as most beneficial. Medications that decrease heavy drinking, such as naltrexone, or that treat opioid dependence, including methadone and buprenorphine, may improve adherence to ART and quality of care and might therefore take precedence over other types of medication [190, 191]. When available, comparative effectiveness data among those with HIV should guide medication choices. Similarly, the risk/benefit ratio of medications when used specifically in HIV-infected patients should be considered before initiating them. For example, Womack and colleagues found that, specifically among HIV-infected patients, proton pump inhibitors are associated with a 55\% increased risk of fracture $(\mathrm{HR}=1.55$ [95 \% CI 1.28, 1.89]) [77]. Given the increased prevalence of bone disease among HIV-infected patients $[78,192]$, the common use of PPIs $[43,77]$ is especially concerning for older, HIV-infected patients. Also consider whether medications (other than ART) that have been poorly adhered to are associated with unwelcome symptoms 
and should be discontinued. Finally, increasingly tough criteria should be used for the continuation of medications ranked lower than 5 th, 7 th, or 10th on the priority list, since risk of harm increases substantially with these thresholds [32-34]. Nonprescription alternatives, including behavioral interventions and prevention counseling, should be considered and utilized when appropriate [15]. Further, medications such as bisphosphonates may not be indicated for osteoporosis prevention if only short-term survival is expected based upon the VACS Index.

In collaboration with patients, providers should determine which medications will be stopped and which ones started, how medication effectiveness will be monitored for therapeutic and adverse effects, and when additional changes might be considered. Techniques for improving adherence to high-priority medications beyond simply stopping other medications should be reviewed. Methods for deciding when to start or stop medications ought to be established with the initiation of new medications. Importantly, by incorporating patient preferences and jointly ranking medications, providers may improve the patient's ability and willingness to adhere to high-priority medications and the completeness with which they report their total medication list to their provider.

\subsection{Role of Clinical Decision Support Systems}

Only one study reviewed by the Cochrane Collaboration used a computerized clinical decision support (CDS) intervention, but it decreased inappropriate and increased appropriate polypharmacy [1]. Healthcare clinics and systems that have access to computerized pharmacy dispensing records have a clear advantage in that these could be used as an excellent starting point for generating a list of medications and level of adherence. However, providers should be careful to ascertain and record medication obtained outside and to develop standard methods to include this documentation within the database. This practice is now routine within the VA Healthcare System. CDS could also be used to estimate risk of ADR and mortality by calculating the VACS Index based upon routine laboratory values and to screen for likely drug-drug interactions (so long as the electronic pharmacy list is complete and accurate). An excellent example of an effective CDS in the management of individuals aging with HIV is that by Robbins et al. [143].

\section{Conclusions and Future Directions}

In the same way that HIV providers are less comfortable with general medicine [136], primary care providers are less knowledgeable about HIV [193]. In the era of cART success and the management of HIV infection as a chronic disease, integrated systems of care, including HIV specialists, primary care and clinical pharmacists [194], and integrated information systems facilitating excellent communication will be essential for optimizing the care of older, HIVinfected patients [137, 138]. Given the changing face of the HIV epidemic, providers will be increasingly challenged to effectively manage older, HIV-infected patients with multimorbidity. Future research efforts should focus on determining the safety and efficacy of cART regimens in older patients and their long-tem effects, and address the larger issue of polypharmacy considering both HIV and non-HIV medications. Strategies to optimize appropriate polypharmacy for HIV-infected patients need to be adapted from prior work outside HIV and evaluated among those aging with HIV. A critical component will include risk assessment, such as that offered by the VACS Index, to inform the prioritization of medications according to their risks and benefits for each patient. In addition, efforts to promote public health initiatives, behavior change, and prevention aimed at reducing polypharmacy should be investigated. Finally, the efforts to tailor polypharmacy interventions to those aging with HIV may provide an important template for adapting these interventions to other complex chronic diseases in which there is a "primary condition" which takes precedence, as would be true of many forms of cancer or severe diabetes. Investigations of the transportability of such approaches to different settings, including to non-Western countries, are needed.

Acknowledgements and Disclosures Dr. David Fiellin has received honoraria from Pinney Associates and Paragon Rx to serve on external advisory boards to monitor the abuse and diversion of buprenorphine.

This work received funding support from the Veterans Aging Cohort study, generously supported by the National Institute on Alcohol and Alcohol Abuse (3U01 AA 13566), the National Institute of Aging (K23 AG00826), the Robert Wood Johnson Generalist Faculty Scholar Award, an Inter-agency Agreement between the National Institute on Aging, the National Institute of Mental Health, and the Veterans Health Administration, as well as the Veterans Health Administration Office of Research and Development and Public Health Strategic Health Care Group.

The views expressed in this article are those of the authors and do not necessarily reflect the position or policy of the Department of Veterans Affairs.

\section{References}

1. Patterson SM, Hughes C, Kerse N, Cardwell Chris R, Bradley Marie C. Interventions to improve the appropriate use of polypharmacy for older people. Cochrane Database Syst Rev. 2012;(5):CD008165. http://www.mrw.interscience.wiley.com/ cochrane/clsysrev/articles/CD008165/frame.html.

2. Hovstadius B, Petersson G. Factors leading to excessive polypharmacy. Clin Geriatr Med. 2012;28(2):159-72. 
3. Anthierens S, Tansens A, Petrovic M, Christiaens T. Qualitative insights into general practitioners views on polypharmacy. BMC Fam Pract. 2010;11:65.

4. Hughes LD, McMurdo ME, Guthrie B. Guidelines for people not for diseases: the challenges of applying UK clinical guidelines to people with multimorbidity. Age Ageing. 2013;42(1): $62-9$.

5. Lugtenberg M, Burgers JS, Westert GP. Effects of evidencebased clinical practice guidelines on quality of care: a systematic review. Qual Saf Health Care. 2009;18(5):385-92.

6. Moen J, Norrgard S, Antonov K, Nilsson JL, Ring L. GPs' perceptions of multiple-medicine use in older patients. J Eval Clin Pract. 2010;16(1):69-75.

7. Shah BM, Hajjar ER. Polypharmacy, adverse drug reactions, and geriatric syndromes. Clin Geriatr Med. 2012;28(2):173-86.

8. Salazar JA, Poon I, Nair M. Clinical consequences of polypharmacy in elderly: expect the unexpected, think the unthinkable. Expert Opin Drug Saf. 2007;6(6):695-704.

9. Lohse N, Hansen AB, Pedersen G, Kronborg G, Gerstoft J, Sorensen HT, et al. Survival of persons with and without HIV infection in Denmark, 1995-2005. Ann Intern Med. 2007;146(2):87-95.

10. Palella FJ Jr, Baker RK, Moorman AC, Chmiel JS, Wood KC, Brooks JT, et al. Mortality in the highly active antiretroviral therapy era: changing causes of death and disease in the HIV outpatient study. J Acquir Immune Defic Syndr. 2006;43(1): 27-34.

11. The Antiretroviral Therapy Cohort Collaboration. Life expectancy of individuals on combination antiretroviral therapy in high-income countries: a collaborative analysis of 14 cohort studies. Lancet. 2008;372(9635):293-9.

12. Hasse B, Ledergerber B, Furrer H, Battegay M, Hirschel B, Cavassini M, et al. Morbidity and aging in HIV-infected persons: the Swiss HIV cohort study. Clin Infect Dis. 2011;53(11):1130-9.

13. Krentz HB, Cosman I, Lee K, Ming JM, Gill MJ. Pill burden in HIV infection: 20 years of experience. Antivir Ther. 2012;17(5): 833-40.

14. Steinman MA, Hanlon JT. Managing medications in clinically complex elders: "There's got to be a happy medium". JAMA. 2010;304(14):1592-601.

15. Schiff GD, Galanter WL, Duhig J, Lodolce AE, Koronkowski MJ, Lambert BL. Principles of conservative prescribing. Arch Intern Med. 2011;171(16):1433-40.

16. Scott IA, Gray LC, Martin JH, Mitchell CA. Minimizing inappropriate medications in older populations: a 10-step conceptual framework. Am J Med. 2012;125(6):529-37.e4.

17. Workgroup for HIV and Aging Consensus Project. Recommended treatment strategies for clinicians managing older patients with HIV. 2011. http://www.aahivm.org/Upload Module/upload/HIV\%20and\%20Aging/Aging\%20report\%20 working\%20document\%20FINAL\%2012.1.pdf

18. Hanna DB, Selik RM, Tang T, Gange SJ. Disparities among US states in HIV-related mortality in persons with HIV infection, 2001-2007. AIDS. 2012;26(1):95-103.

19. High KP, Brennan-Ing M, Clifford DB, Cohen MH, Currier J, Deeks SG, et al. HIV and aging: state of knowledge and areas of critical need for research. A report to the NIH Office of AIDS Research by the HIV and Aging Working Group. J Acquir Immune Defic Syndr. 2012;60(Suppl 1):S1-18.

20. Justice AC. HIV and aging: time for a new paradigm. Curr HIV/ AIDS Rep. 2010;7(2):69-76.

21. Deeks SG, Phillips AN. HIV infection, antiretroviral treatment, ageing, and non-AIDS related morbidity. BMJ. 2009;338:a3172.

22. Panel on Antiretroviral Guidelines for Adults and Adolescents. Guidelines for the use of antiretroviral agents in HIV-1-infected adults and adolescents. 2012. http://aidsinfo.nih.gov/guidelines/ $\mathrm{html} / 1 /$ adult-and-adolescent-arv-guidelines/0

23. Gilbert Welch H, Schwartz L, Woloshin S. Overdiagnosed: making people sick in the pursuit of health. Boston: Beacon Press; 2011.

24. Joshi D, O'Grady J, Dieterich D, Gazzard B, Agarwal K. Increasing burden of liver disease in patients with HIV infection. Lancet. 2011;377(9772):1198-209.

25. Lucas GM, Mehta SH, Atta MG, Kirk GD, Galai N, Vlahov D, et al. End-stage renal disease and chronic kidney disease in a cohort of African-American HIV-infected and at-risk HIVseronegative participants followed between 1988 and 2004. AIDS. 2007;21(18):2435-43.

26. Medapalli RK, Parikh CR, Gordon K, Brown ST, Butt AA, Gibert CL, et al. Comorbid diabetes and the risk of progressive chronic kidney disease in HIV-infected adults: data from the Veterans Aging Cohort Study. J Acquir Immune Defic Syndr. 2012;60(4):393-9.

27. Islam FM, Wu J, Jansson J, Wilson DP. Relative risk of renal disease among people living with HIV: a systematic review and meta-analysis. BMC Public Health. 2012;12:234.

28. Nguyen GC, Sam J, Thuluvath PJ. Hepatitis C is a predictor of acute liver injury among hospitalizations for acetaminophen overdose in the United States: a nationwide analysis. Hepatology. 2008;48(4):1336-41.

29. Prosperi MC, Fabbiani M, Fanti I, Zaccarelli M, Colafigli M, Mondi A, et al. Predictors of first-line antiretroviral therapy discontinuation due to drug-related adverse events in HIVinfected patients: a retrospective cohort study. BMC Infect Dis. 2012;12:296

30. Lo Re V 3rd, Kostman JR, Amorosa VK. Management complexities of HIV/hepatitis $\mathrm{C}$ virus coinfection in the twenty-first century. Clin Liver Dis. 2008;12(3):587-609, ix.

31. Colley CA, Lucas LM. Polypharmacy: the cure becomes the disease. J Gen Intern Med. 1993;8(5):278-83.

32. Jyrkka J, Enlund H, Lavikainen P, Sulkava R, Hartikainen S. Association of polypharmacy with nutritional status, functional ability and cognitive capacity over a three-year period in an elderly population. Pharmacoepidemiol Drug Saf. 2011;20(5): 514-22.

33. Gandhi TK, Weingart SN, Borus J, Seger AC, Peterson J, Burdick E, et al. Adverse drug events in ambulatory care. N Engl J Med. 2003;348(16):1556-64.

34. Jyrkka J, Enlund H, Korhonen MJ, Sulkava R, Hartikainen S. Polypharmacy status as an indicator of mortality in an elderly population. Drugs Aging. 2009;26(12):1039-48.

35. Marcum ZA, Amuan ME, Hanlon JT, Aspinall SL, Handler SM, Ruby CM, et al. Prevalence of unplanned hospitalizations caused by adverse drug reactions in older veterans. J Am Geriatr Soc. 2012;60(1):34-41.

36. Richardson K, Ananou A, Lafortune L, Brayne C, Matthews FE. Variation over time in the association between polypharmacy and mortality in the older population. Drugs Aging. 2011;28(7):547-60

37. Gnjidic D, Hilmer SN, Blyth FM, Naganathan V, Waite L, Seibel MJ, et al. Polypharmacy cutoff and outcomes: five or more medicines were used to identify community-dwelling older men at risk of different adverse outcomes. J Clin Epidemiol. 2012;65(9):989-95.

38. Clay PG. Actual medication pill burden and dosing frequency in HIV-infected patients with undetectable viral loads. J Int Assoc Physicians AIDS Care (Chic). 2004;3(2):49-55.

39. Furler MD, Einarson TR, Walmsley S, Millson M, Bendayan R. Polypharmacy in HIV: impact of data source and gender on reported drug utilization. AIDS Patient Care STDS. 2004; 18(10):568-86. 
40. Nachega JB, Hsu AJ, Uthman OA, Spinewine A, Pham PA. Antiretroviral therapy adherence and drug-drug interactions in the aging HIV population. AIDS. 2012;26(Suppl 1):S39-53.

41. Marzolini C, Elzi L, Gibbons S, Weber R, Fux C, Furrer H, et al. Prevalence of comedications and effect of potential drug-drug interactions in the Swiss HIV cohort study. Antivir Ther. 2010;15(3):413-23.

42. Guaraldi G, Menozzi M, Zona S, Garlassi E, Berti A, Rossi E, et al. Polypharmacology for polypathology in HIV infected patients. Antivi Ther. 2010;15:A31.

43. Marzolini C, Back D, Weber R, Furrer H, Cavassini M, Calmy A, et al. Ageing with HIV: medication use and risk for potential drug-drug interactions. J Antimicrob Chemother. 2011;66(9): 2107-11.

44. Ajuoga E, Sansgiry SS, Ngo C, Yeh RF. Use/misuse of over-thecounter medications and associated adverse drug events among HIV-infected patients. Res Social Adm Pharm. 2008;4(3): 292-301.

45. Littlewood RA, Vanable PA. Complementary and alternative medicine use among HIV-positive people: research synthesis and implications for HIV care. AIDS Care. 2008;20(8):1002-18.

46. Barry DT, Goulet JL, Kerns RK, Becker WC, Gordon AJ, Justice AC, et al. Nonmedical use of prescription opioids and pain in veterans with and without HIV. Pain. 2011;152(5):1133-8.

47. Walensky RP, Paltiel AD, Losina E, Mercincavage LM, Schackman BR, Sax PE, et al. The survival benefits of AIDS treatment in the United States. J Infect Dis. 2006;194(1):11-9.

48. Molina JM, Cahn P, Grinsztejn B, Lazzarin A, Mills A, Saag M, et al. Rilpivirine versus efavirenz with tenofovir and emtricitabine in treatment-naive adults infected with HIV-1 (ECHO): a phase 3 randomised double-blind active-controlled trial. Lancet. 2011;378(9787):238-46.

49. Daar ES, Tierney C, Fischl MA, Sax PE, Mollan K, Budhathoki $\mathrm{C}$, et al. Atazanavir plus ritonavir or efavirenz as part of a 3-drug regimen for initial treatment of HIV-1: a randomized trial. Ann Intern Med. 2011;154(7):445-56.

50. Gotuzzo E, Markowitz M, Ratanasuwan W, Smith G, Prada G, Morales-Ramirez JO, et al. Sustained efficacy and safety of raltegravir after 5 years of combination antiretroviral therapy as initial treatment of HIV-1 infection: final results of a randomized, controlled, phase II study (Protocol 004). J Acquir Immune Defic Syndr. 2012;61(1):73-7.

51. Gebo KA. HIV and aging: implications for patient management. Drugs Aging. 2006;23(11):897-913.

52. Gebo KA, Justice A. HIV infection in the elderly. Curr Infect Dis Rep. 2009;11(3):246-54.

53. Reisler RB, Han C, Burman WJ, Tedaldi EM, Neaton JD. Grade 4 events are as important as AIDS events in the era of HAART. J Acquir Immune Defic Syndr. 2003;34(4):379-86.

54. Bedimo R, Maalouf NM, Zhang S, Drechsler H, Tebas P. Osteoporotic fracture risk associated with cumulative exposure to tenofovir and other antiretroviral agents. AIDS. 2012;26(7): 825-31.

55. Laprise C, Baril JG, Dufresne S, Trottier H. Association between tenofovir exposure and reduced kidney function in a cohort of HIV-positive patients: results from 10 years of followup. Clin Infect Dis. 2013;56(4):567-75.

56. Cooper RD, Wiebe N, Smith N, Keiser P, Naicker S, Tonelli M. Systematic review and meta-analysis: renal safety of tenofovir disoproxil fumarate in HIV-infected patients. Clin Infect Dis. 2010;51(5):496-505.

57. Scherzer R, Estrella M, Li Y, Choi AI, Deeks SG, Grunfeld C, et al. Association of tenofovir exposure with kidney disease risk in HIV infection. AIDS. 2012;26(7):867-75.

58. Gellad WF, Grenard JL, Marcum ZA. A systematic review of barriers to medication adherence in the elderly: looking beyond cost and regimen complexity. Am J Geriatr Pharmacother. 2011;9(1):11-23.

59. Marcum ZA, Gellad WF. Medication adherence to multidrug regimens. Clin Geriatr Med. 2012;28(2):287-300.

60. Stone VE, Hogan JW, Schuman P, Rompalo AM, Howard AA, Korkontzelou C, et al. Antiretroviral regimen complexity, selfreported adherence, and HIV patients' understanding of their regimens: survey of women in the HER study. J Acquir Immune Defic Syndr. 2001;28(2):124-31.

61. Atkinson MJ, Petrozzino JJ. An evidence-based review of treatment-related determinants of patients' nonadherence to HIV medications. AIDS Patient Care STDS. 2009;23(11):903-14.

62. Maiese E, Malmenas M, Atkinson M. Impact of comorbidities on HIV medication persistence: a retrospective database study using US claims data. J Int AIDS Soc. 2012;15(Suppl 4):18063.

63. Goulet JL, Fultz SL, Rimland D, Butt A, Gibert C, RodriguezBarradas M, et al. Aging and infectious diseases: do patterns of comorbidity vary by HIV status, age, and HIV severity? Clin Infect Dis. 2007;45(12):1593-601.

64. Heaton RK, Clifford DB, Franklin DR Jr, Woods SP, Ake C, Vaida $\mathrm{F}$, et al. HIV-associated neurocognitive disorders persist in the era of potent antiretroviral therapy: CHARTER Study. Neurology. 2010;75(23):2087-96.

65. Heaton RK, Franklin DR, Ellis RJ, McCutchan JA, Letendre SL, Leblanc $\mathrm{S}$, et al. HIV-associated neurocognitive disorders before and during the era of combination antiretroviral therapy: differences in rates, nature, and predictors. $J$ Neurovirol. 2011;17(1):3-16.

66. Anema A, Weiser SD, Fernandes KA, Ding E, Brandson EK, Palmer A, et al. High prevalence of food insecurity among HIVinfected individuals receiving HAART in a resource-rich setting. AIDS Care. 2011;23(2):221-30.

67. Crystal S, Akincigil A, Sambamoorthi U, Wenger N, Fleishman JA, Zingmond DS, et al. The diverse older HIV-positive population: a national profile of economic circumstances, social support, and quality of life. J Acquir Immune Defic Syndr. 2003;33(Suppl 2):S76-83.

68. Braithwaite RS, McGinnis KA, Conigliaro J, Maisto SA, Crystal $\mathrm{S}$, Day $\mathrm{N}$, et al. A temporal and dose-response association between alcohol consumption and medication adherence among veterans in care. Alcohol Clin Exp Res. 2005;29(7):1190-7.

69. Kalichman SC, Pellowski J, Kalichman MO, Cherry C, Detorio $\mathrm{M}$, Caliendo AM, et al. Food insufficiency and medication adherence among people living with HIV/AIDS in urban and peri-urban settings. Prev Sci. 2011;12(3):324-32.

70. Huang AR, Mallet L, Rochefort CM, Eguale T, Buckeridge DL, Tamblyn R. Medication-related falls in the elderly: causative factors and preventive strategies. Drugs Aging. 2012;29(5):359-76.

71. Huang ES, Karter AJ, Danielson KK, Warton EM, Ahmed AT. The association between the number of prescription medications and incident falls in a multi-ethnic population of adult type-2 diabetes patients: the Diabetes and Aging Study. J Gen Intern Med. 2010;25(2):141-6.

72. Tinetti ME. Clinical practice. Preventing falls in elderly persons. N Engl J Med. 2003;348(1):42-9.

73. Tinetti ME, Kumar C. The patient who falls: "It's always a trade-off". JAMA. 2010;303(3):258-66.

74. Deandrea S, Lucenteforte E, Bravi F, Foschi R, La Vecchia C, Negri E. Risk factors for falls in community-dwelling older people: a systematic review and meta-analysis. Epidemiology. 2010;21(5):658-68.

75. Kaptoge S, Benevolenskaya LI, Bhalla AK, Cannata JB, Boonen $\mathrm{S}$, Falch JA, et al. Low BMD is less predictive than reported falls for future limb fractures in women across Europe: results from the European Prospective Osteoporosis Study. Bone. 2005;36(3):387-98. 
76. Collin F, Duval X, Le Moing V, Piroth L, Al Kaied F, Massip P, et al. Ten-year incidence and risk factors of bone fractures in a cohort of treated HIV1-infected adults. AIDS. 2009;23(8):1021-4.

77. Womack JA, Goulet JL, Gibert C, Brandt C, Chang CC, Gulanski B, et al. Increased risk of fragility fractures among HIV infected compared to uninfected male veterans. PLoS One. 2011;6(2):e17217.

78. McComsey GA, Tebas P, Shane E, Yin MT, Overton ET, Huang $\mathrm{JS}$, et al. Bone disease in HIV infection: a practical review and recommendations for HIV care providers. Clin Infect Dis. 2010;51(8):937-46.

79. Erlandson KM, Allshouse AA, Jankowski CM, Duong S, Mawhinney S, Kohrt WM, et al. Risk factors for falls in HIVinfected persons. J Acquir Immune Defic Syndr. 2012;61(4): 484-9.

80. Valcour V, Paul R, Chiao S, Wendelken LA, Miller B. Screening for cognitive impairment in human immunodeficiency virus. Clin Infect Dis. 2011;53(8):836-42.

81. Espino DV, Bazaldua OV, Palmer RF, Mouton CP, Parchman ML, Miles TP, et al. Suboptimal medication use and mortality in an older adult community-based cohort: results from the Hispanic EPESE Study. J Gerontol A Biol Sci Med Sci. 2006;61(2):170-5.

82. Akgun KM, Gordon K, Pisani M, Fried T, McGinnis KA, Tate $\mathrm{JP}$, et al. Risk factors for hospitalization and medical intensive care unit (MICU) admission among HIV infected veterans. J Acquir Immune Defic Syndr. 2013;62(1):52-9.

83. Justice A, Modur S, Tate J, Althoff K, Jacobson L, Gebo K, et al. Predictive accuracy of the Veterans Aging Cohort Study (VACS) index for mortality with HIV infection: a north American cross cohort analysis. J Acquir Immune Defic Syndr. 2013;62(2):149-63.

84. Justice AC, McGinnis KA, Skanderson M, et al. Towards a combined prognostic index for survival in HIV infection: the role of 'non-HIV' biomarkers. HIV Med. 2010;11(2):143-51.

85. Tate JP, Justice AC, Hughes MD, Bonnet F, Reiss P, Mocroft A, et al. The VACS index: an internationally generalizable risk index for mortality after one year of antiretroviral therapy. AIDS. 2013;27(4):563-72.

86. Chang CB, Chan DC. Comparison of published explicit criteria for potentially inappropriate medications in older adults. Drugs Aging. 2010;27(12):947-57.

87. Lipton HL, Bero LA, Bird JA, McPhee SJ. The impact of clinical pharmacists' consultations on physicians' geriatric drug prescribing. A randomized controlled trial. Med Care. 1992;30(7):646-58.

88. Pugh MJ, Hanlon JT, Wang CP, Semla T, Burk M, Amuan ME, et al. Trends in use of high-risk medications for older veterans: 2004 to 2006. J Am Geriatr Soc. 2011;59(10):1891-8.

89. Steinman MA, Landefeld CS, Rosenthal GE, Berthenthal D, Sen S, Kaboli PJ. Polypharmacy and prescribing quality in older people. J Am Geriatr Soc. 2006;54(10):1516-23.

90. Korthuis PT, Fiellin DA, Fu R, Lum PJ, Altice FL, Sohler N, et al. Improving adherence to HIV quality of care indicators in persons with opioid dependence: the role of buprenorphine. J Acquir Immune Defic Syndr. 2011;56(Suppl 1):S83-90.

91. Korthuis PT, Fiellin DA, McGinnis KA, Skanderson M, Justice $\mathrm{AC}$, Gordon AJ, et al. Unhealthy alcohol and illicit drug use are associated with decreased quality of HIV care. J Acquir Immune Defic Syndr. 2012;61(2):171-8.

92. DeLorenze GN, Follansbee SF, Nguyen DP, Klein DB, Horberg M, Quesenberry CP Jr., et al. Medication error in the care of HIV/AIDS patients: electronic surveillance, confirmation, and adverse events. Med Care. 2005;43(9 Suppl):III63-8.

93. Hellinger FJ, Encinosa WE. Inappropriate drug combinations among privately insured patients with HIV disease. Med Care. 2005;43(9 Suppl):III53-62.
94. Hellinger FJ, Encinosa WE. The cost and incidence of prescribing errors among privately insured HIV patients. Pharmacoeconomics. 2010;28(1):23-34.

95. Silverberg MJ, Ray GT, Saunders K, Rutter CM, Campbell CI, Merrill JO, et al. Prescription long-term opioid use in HIVinfected patients. Clin J Pain. 2012;28(1):39-46.

96. Edelman EJ, Gordon K, Becker WC, Goulet JL, Skanderson M, Gaither JR, et al. Receipt of opioid analgesics by HIVinfected and uninfected patients. J Gen Intern Med. 2013;28(1):82-90.

97. Koeppe J, Armon C, Lyda K, Nielsen C, Johnson S. Ongoing pain despite aggressive opioid pain management among persons with HIV. Clin J Pain. 2010;26(3):190-8.

98. Lum PJ, Little S, Botsko M, Hersh D, Thawley RE, Egan JE, et al. Opioid-prescribing practices and provider confidence recognizing opioid analgesic abuse in HIV primary care settings. J Acquir Immune Defic Syndr. 2011;56(Suppl 1):S91-7.

99. Onen NF, Barrette EP, Shacham E, Taniguchi T, Donovan M, Overton ET. A review of opioid prescribing practices and associations with repeat opioid prescriptions in a contemporary outpatient HIV clinic. Pain Pract. 2012;12(6):440-8.

100. Freiberg MS, Leaf DA, Goulet JL, Goetz MB, Oursler KK, Gibert CL, et al. The association between the receipt of lipid lowering therapy and HIV status among veterans who met NCEP/ATP III criteria for the receipt of lipid lowering medication. J Gen Intern Med. 2009;24(3):334-40.

101. Burkholder GA, Tamhane AR, Salinas JL, Mugavero MJ, Raper $\mathrm{JL}$, Westfall AO, et al. Underutilization of aspirin for primary prevention of cardiovascular disease among HIV-infected patients. Clin Infect Dis. 2012;55(11):1550-7.

102. Edelman EJ, Gordon K, Rodriguez-Barradas MC, Justice AC. Patient-reported symptoms on the antiretroviral regimen efavirenz/emtricitabine/tenofovir. AIDS Patient Care STDS. 2012;26(6):312-9.

103. Armah KA, McGinnis K, Baker J, Gibert C, Butt AA, Bryant $\mathrm{KJ}$, et al. HIV status, burden of comorbid disease, and biomarkers of inflammation, altered coagulation, and monocyte activation. Clin Infect Dis. 2012;55(1):126-36.

104. Womack J, Goulet J, Gibert C, Brandt C, Skanderson M, Gulanski B, et al. Physiologic frailty and fragility fracture in HIV infected male Veterans. Clin Infect Dis. 2013;56(10):1498-504.

105. Marquine MJ, Moore DJ, Gouaux B, Rooney A, Woods SP, Letendre SL, Ellis RJ, Grant I, HNRP group. Higher Veterans Aging Cohort Study (VACS) index scores are associated with concurrent risk of neurocognitive impairment. In: International HIV and Aging Workshop, 2012

106. Gallagher LP. The potential for adverse drug reactions in elderly patients. Appl Nurs Res. 2001;14(4):220-4.

107. Yiu P, Nguyen NN, Holodniy M. Clinically significant drug interactions in younger and older human immunodeficiency virus-positive patients receiving antiretroviral therapy. Pharmacotherapy. 2011;31(5):480-9.

108. Pau AK, Boyd SD. Recognition and management of significant drug interactions in HIV patients: challenges in using available data to guide therapy. Clin Pharmacol Ther. 2010;88(5):712-9.

109. Furler MD, Einarson TR, Walmsley S, Millson M, Bendayan R. Polypharmacy in HIV: impact of data source and gender on reported drug utilization. AIDS Patient Care STDS. 2004;18(10):568-86.

110. Parenti P, Marconi L, Lupo S. Hepatotoxicity of antiretrovirals in patients with human immunodeficiency virus and viral hepatitis coinfections. J Int AIDS Soc. 2012;15(6):18431.

111. Green TC, Kershaw T, Lin H, Heimer R, Goulet JL, Kraemer $\mathrm{KL}$, et al. Patterns of drug use and abuse among aging adults with and without HIV: a latent class analysis of a US Veteran cohort. Drug Alcohol Depend. 2010;110(3):208-20. 
112. Mallet L, Spinewine A, Huang A. The challenge of managing drug interactions in elderly people. Lancet. 2007;370 (9582):185-91.

113. Lucas GM, Gebo KA, Chaisson RE, Moore RD. Longitudinal assessment of the effects of drug and alcohol abuse on HIV-1 treatment outcomes in an urban clinic. AIDS. 2002;16(5): 767-74.

114. Baum MK, Rafie C, Lai S, Sales S, Page B, Campa A. Crackcocaine use accelerates HIV disease progression in a cohort of HIV-positive drug users. J Acquir Immune Defic Syndr. 2009;50(1):93-9.

115. Moore DJ, Blackstone K, Woods SP, Ellis RJ, Atkinson JH, Heaton RK, et al. Methamphetamine use and neuropsychiatric factors are associated with antiretroviral non-adherence. AIDS Care. 2012;24(12):1504-13.

116. Conney AH, Reidenberg MM. Cigarette smoking, coffee drinking, and ingestion of charcoal-broiled beef as potential modifiers of drug therapy and confounders of clinical trials. J Pharmacol Exp Ther. 2012;342(1):9-14.

117. Kroon LA. Drug interactions with smoking. Am J Health Syst Pharm. 2007;64(18):1917-21.

118. Heppner HJ, Christ M, Gosch M, Muhlberg W, Bahrmann P, Bertsch T, et al. Polypharmacy in the elderly from the clinical toxicologist perspective. Z Gerontol Geriatr. 2012;45(6):473-8.

119. Moore AA, Whiteman EJ, Ward KT. Risks of combined alcohol/medication use in older adults. Am J Geriatr Pharmacother. 2007;5(1):64-74.

120. Johnson EM, Lanier WA, Merrill RM, Crook J, Porucznik CA, Rolfs RT, et al. Unintentional prescription opioid-related overdose deaths: description of decedents by next of kin or best contact, Utah, 2008-2009. J Gen Intern Med. 2012;28(4):522-9.

121. Dunn KM, Saunders KW, Rutter CM, Banta-Green CJ, Merrill JO, Sullivan MD, et al. Opioid prescriptions for chronic pain and overdose: a cohort study. Ann Intern Med. 2010;152(2):85-92.

122. Hall AJ, Logan JE, Toblin RL, Kaplan JA, Kraner JC, Bixler D, et al. Patterns of abuse among unintentional pharmaceutical overdose fatalities. JAMA. 2008;300(22):2613-20.

123. Lindsey WT, Stewart D, Childress D. Drug interactions between common illicit drugs and prescription therapies. Am J Drug Alcohol Abuse. 2012;38(4):334-43.

124. Willig JH, Westfall AO, Allison J, Van Wagoner N, Chang PW, Raper J, et al. Nucleoside reverse-transcriptase inhibitor dosing errors in an outpatient HIV clinic in the electronic medical record era. Clin Infect Dis. 2007;45(5):658-61.

125. Edelman EJ, Gordon KS, Lo Re III V, Skanderson M, Fiellin DA, Justice AC. Acetaminophen receipt among HIV-infected patients with advanced hepatic fibrosis. Pharmacoepidemiol Drug Saf. (in review).

126. Rebeiro P, Althoff KN, Buchacz K, et al. Retention among north American HIV-infected persons in clinical care, 2000-2008. J Acquir Immune Defic Syndr. 2012. [Epub ahead of print].

127. Fleishman JA, Yehia BR, Moore RD, Korthuis PT, Gebo KA. Establishment, retention, and loss to follow-up in outpatient HIV care. J Acquir Immune Defic Syndr. 2012;60(3):249-59.

128. Fournier PO, Savageau JA, Baldor RA. A shift in referral patterns for HIV/AIDS patients. J Fam Pract. 2008;57(2):E1-9.

129. Duffus WA, Barragan M, Metsch L, Krawczyk CS, Loughlin AM, Gardner LI, et al. Effect of physician specialty on counseling practices and medical referral patterns among physicians caring for disadvantaged human immunodeficiency virusinfected populations. Clin Infect Dis. 2003;36(12):1577-84.

130. Loy A, Townsend L, O'Dea S, Mulcahy F. Management of dyslipidaemia in an HIV-positive cohort. J Int AIDS Soc. 2012;15(6): 18128.

131. Benn PD, Miller RF, Evans L, Minton J, Edwards SG. Devolving of statin prescribing to general practitioners for HIV- infected patients receiving antiretroviral therapy. Int J STD AIDS. 2009;20(3):202-4.

132. Yehia BR, Fleishman JA, Hicks PL, Ridore M, Moore RD, Gebo KA. Inpatient health services utilization among HIV-infected adult patients in care 2002-2007. J Acquir Immune Defic Syndr. 2010;53(3):397-404.

133. Yehia BR, Mehta JM, Ciuffetelli D, Moore RD, Pham PA, Metlay JP, et al. Antiretroviral medication errors remain high but are quickly corrected among hospitalized HIV-infected adults. Clin Infect Dis. 2012;55(4):593-9.

134. Snyder AM, Klinker K, Orrick JJ, Janelle J, Winterstein AG. An in-depth analysis of medication errors in hospitalized patients with HIV. Ann Pharmacother. 2011;45(4):459-68.

135. Rao N, Patel V, Grigoriu A, Kaushik P, Brizuela M. Antiretroviral therapy prescribing in hospitalized HIV clinic patients. HIV Med. 2012;13(6):367-71.

136. Fultz SL, Goulet JL, Weissman S, Rimland D, Leaf D, Gibert C, et al. Differences between infectious diseases-certified physicians and general medicine-certified physicians in the level of comfort with providing primary care to patients. Clin Infect Dis. 2005;41(5):738-43.

137. Waters L, Patterson B, Scourfield A, Hughes A, de Silva S, Gazzard B, et al. A dedicated clinic for HIV-positive individuals over 50 years of age: a multidisciplinary experience. Int J STD AIDS. 2012;23(8):546-52.

138. Chu C, Selwyn PA. An epidemic in evolution: the need for new models of HIV care in the chronic disease era. J Urban Health. 2011;88(3):556-66.

139. Gallagher P, Ryan C, Byrne S, Kennedy J, O’Mahony D. STOPP (Screening Tool of Older Person's Prescriptions) and START (Screening Tool to Alert doctors to Right Treatment). Consensus validation. Int J Clin Pharmacol Ther. 2008;46(2): 72-83.

140. Beers MH, Ouslander JG, Rollingher I, Reuben DB, Brooks J, Beck JC. Explicit criteria for determining inappropriate medication use in nursing home residents. UCLA Division of Geriatric Medicine. Arch Intern Med. 1991;151(9):1825-32.

141. Fitzgerald LS, Hanlon JT, Shelton PS, Landsman PB, Schmader KE, Pulliam CC, et al. Reliability of a modified medication appropriateness index in ambulatory older persons. Ann Pharmacother. 1997;31(5):543-8.

142. Hilmer SN, Mager DE, Simonsick EM, Cao Y, Ling SM, Windham BG, et al. A drug burden index to define the functional burden of medications in older people. Arch Intern Med. 2007;167(8):781-7.

143. Robbins GK, Lester W, Johnson KL, Chang Y, Estey G, Surrao $\mathrm{D}$, et al. Efficacy of a clinical decision-support system in an HIV practice: a randomized trial. Ann Intern Med. 2012;157(11): 757-66.

144. Edelman EJ, Gordon K, Justice AC. Patient and providerreported symptoms in the post-cART era. AIDS Behav. 2011;15(4):853-61.

145. Braithwaite RS, Fiellin D, Justice AC. The payoff time: a flexible framework to help clinicians decide when patients with comorbid disease are not likely to benefit from practice guidelines. Med Care. 2009;47(6):610-7.

146. Sigel K, Dubrow R, Silverberg M, Crothers K, Braithwaite S, Justice A. Cancer screening in patients infected with HIV. Curr HIV/AIDS Rep. 2011;8(3):142-52.

147. Singer SR, Hoshen M, Shadmi E, Leibowitz M, Flaks-Manov N, Bitterman $\mathrm{H}$, et al. EMR-based medication adherence metric markedly enhances identification of nonadherent patients. Am J Manag Care. 2012;18(10):e372-7.

148. Bonn-Miller MO, Oser ML, Bucossi MM, Trafton JA. Cannabis use and HIV antiretroviral therapy adherence and HIV-related symptoms. J Behav Med. 2012. [Epub ahead of print]. 
149. McCance-Katz EF, Rainey PM, Smith P, Morse GD, Friedland G, Boyarsky B, et al. Drug interactions between opioids and antiretroviral medications: interaction between methadone, LAAM, and delavirdine. Am J Addict. 2006;15(1):23-34.

150. Corless IB, Lindgren T, Holzemer W, Robinson L, Moezzi S, Kirksey K, et al. Marijuana effectiveness as an HIV self-care strategy. Clin Nurs Res. 2009;18(2):172-93.

151. McCance-Katz EF, Sullivan LE, Nallani S. Drug interactions of clinical importance among the opioids, methadone and buprenorphine, and other frequently prescribed medications: a review. Am J Addict. 2010;19(1):4-16.

152. Antoniou T, Tseng AL. Interactions between recreational drugs and antiretroviral agents. Ann Pharmacother. 2002;36(10):1598-613.

153. Gruber VA, McCance-Katz EF. Methadone, buprenorphine, and street drug interactions with antiretroviral medications. Curr HIV/AIDS Rep. 2010;7(3):152-60.

154. Gonzalez A, Mimiaga MJ, Israel J, Andres Bedoya C, Safren SA. Substance use predictors of poor medication adherence: the role of substance use coping among HIV-infected patients in opioid dependence treatment. AIDS Behav. 2013;17(1):168-73.

155. Arnsten JH, Demas PA, Grant RW, Gourevitch MN, Farzadegan $\mathrm{H}$, Howard AA, et al. Impact of active drug use on antiretroviral therapy adherence and viral suppression in HIV-infected drug users. J Gen Intern Med. 2002;17(5):377-81.

156. Rosen MI, Black AC, Arnsten JH, Goggin K, Remien RH, Simoni JM, et al. Association between use of specific drugs and antiretroviral adherence: findings from MACH 14. AIDS Behav. 2013;17(1):142-7.

157. Hendershot CS, Stoner SA, Pantalone DW, Simoni JM. Alcohol use and antiretroviral adherence: review and meta-analysis. J Acquir Immune Defic Syndr. 2009;52(2):180-202.

158. O’Neil CR, Palmer AK, Coulter S, O'Brien N, Shen A, Zhang $\mathrm{W}$, et al. Factors associated with antiretroviral medication adherence among HIV-positive adults accessing highly active antiretroviral therapy (HAART) in British Columbia, Canada. J Int Assoc Physicians AIDS Care (Chic). 2012;11(2):134-41.

159. Shuter J, Bernstein SL. Cigarette smoking is an independent predictor of nonadherence in HIV-infected individuals receiving highly active antiretroviral therapy. Nicotine Tob Res. 2008;10(4):731-6.

160. Peretti-Watel P, Spire B, Lert F, Obadia Y. Drug use patterns and adherence to treatment among HIV-positive patients: evidence from a large sample of French outpatients (ANRS-EN12VESPA 2003). Drug Alcohol Depend. 2006;82(Suppl 1):S71-9.

161. Sullivan PS, Campsmith ML, Nakamura GV, Begley EB, Schulden J, Nakashima AK. Patient and regimen characteristics associated with self-reported nonadherence to antiretroviral therapy. PLoS One. 2007;2(6):e552.

162. Hinkin CH, Barclay TR, Castellon SA, Levine AJ, Durvasula RS, Marion SD, et al. Drug use and medication adherence among HIV-1 infected individuals. AIDS Behav. 2007;11(2): 185-94.

163. Bush K, Kivlahan DR, McDonell MB, Fihn SD, Bradley KA. The AUDIT alcohol consumption questions (AUDIT-C): an effective brief screening test for problem drinking. Ambulatory care quality improvement project (ACQUIP). Alcohol use disorders identification test. Arch Intern Med. 1998;158(16): 1789-95

164. A clinical practice guideline for treating tobacco use and dependence: a US public health service report. The tobacco use and dependence clinical practice guideline panel, staff, and consortium representatives. JAMA. 2000;283(24):3244-54

165. Allensworth-Davies D, Cheng DM, Smith PC, Samet JH, Saitz R. The short inventory of problems-modified for drug use (SIP-DU): validity in a primary care sample. Am J Addict. 2012;21(3):257-62.
166. Yudko E, Lozhkina O, Fouts A. A comprehensive review of the psychometric properties of the Drug Abuse Screening Test. J Subst Abuse Treat. 2007;32(2):189-98.

167. Smith PC, Schmidt SM, Allensworth-Davies D, Saitz R. A single-question screening test for drug use in primary care. Arch Intern Med. 2010;170(13):1155-60.

168. Hanlon JT, Schmader KE, Samsa GP, Weinberger M, Uttech $\mathrm{KM}$, Lewis IK, et al. A method for assessing drug therapy appropriateness. J Clin Epidemiol. 1992;45(10):1045-51.

169. American Geriatrics Society 2012 Beers Criteria Update Expert Panel. American Geriatrics Society updated Beers Criteria for potentially inappropriate medication use in older adults. J Am Geriatr Soc. 2012;60(4):616-31.

170. Fick DM, Cooper JW, Wade WE, Waller JL, Maclean JR, Beers $\mathrm{MH}$. Updating the Beers criteria for potentially inappropriate medication use in older adults: results of a US consensus panel of experts. Arch Intern Med. 2003;163(22):2716-24.

171. Fick DM, Semla TP. 2012 American Geriatrics Society Beers Criteria: new year, new criteria, new perspective. J Am Geriatr Soc. 2012;60(4):614-5.

172. Lam MPS, Cheung BMY. The use of STOPP/START criteria as a screening tool for assessing the appropriateness of medications in the elderly population. Expert Rev Clin Pharmacol. 2012;5(2):187-97.

173. Hamilton H, Gallagher P, Ryan C, Byrne S, O'Mahony D. Potentially inappropriate medications defined by STOPP criteria and the risk of adverse drug events in older hospitalized patients. Arch Intern Med. 2011;171(11):1013-9.

174. Gallagher P, O’Mahony D. STOPP (Screening Tool of Older Persons' potentially inappropriate Prescriptions): application to acutely ill elderly patients and comparison with Beers' criteria. Age Ageing. 2008;37(6):673-9.

175. Gallagher PF, O'Connor MN, O'Mahony D. Prevention of potentially inappropriate prescribing for elderly patients: a randomized controlled trial using STOPP/START criteria. Clin Pharmacol Ther. 2011;89(6):845-54.

176. Alfaro Lara ER, Vega Coca MD, Galvan Banqueri M, Marin Gil $\mathrm{R}$, Nieto Martin MD, Perez Guerrero C, et al. Selection of tools for reconciliation, compliance and appropriateness of treatment in patients with multiple chronic conditions. Eur J Intern Med. 2012;23(6):506-12.

177. National Health Service Cumbria. STOPP START Toolkit supporting Medication Review. 2011. http://www.cumbria. nhs.uk/ProfessionalZone/MedicinesManagement/Guidelines/ StopstartToolkit2011.pdf

178. Triant VA. HIV infection and coronary heart disease: an intersection of epidemics. J Infect Dis. 2012;205(Suppl 3):S355-61.

179. Moore RD, Bartlett JG, Gallant JE. Association between use of HMG CoA reductase inhibitors and mortality in HIV-infected patients. PLoS One. 2011;6(7):e21843.

180. Silverberg MJ, Leyden W, Hurley L, Go AS, Quesenberry CP Jr, Klein D, et al. Response to newly prescribed lipid-lowering therapy in patients with and without HIV infection. Ann Intern Med. 2009;150(5):301-13.

181. Hansen L, Penko J, Guzman D, Bangsberg DR, Miaskowski C, Kushel MB. Aberrant behaviors with prescription opioids and problem drug use history in a community-based cohort of HIVinfected individuals. J Pain Symptom Manage. 2011;42(6): 893-902.

182. Miaskowski C, Penko JM, Guzman D, Mattson JE, Bangsberg DR, Kushel MB. Occurrence and characteristics of chronic pain in a community-based cohort of indigent adults living with HIV infection. J Pain. 2011;12(9):1004-16.

183. Vijayaraghavan M, Penko J, Bangsberg DR, Miaskowski C, Kushel MB. Opioid analgesic misuse in a community-based cohort of HIV-infected indigent adults. JAMA Intern Med. 2013;14:1-3. 
184. Krashin DL, Merrill JO, Trescot AM. Opioids in the management of HIV-related pain. Pain Physician. 2012;15(3 Suppl): ES157-68.

185. Roy S, Ninkovic J, Banerjee S, Charboneau RG, Das S, Dutta R, et al. Opioid drug abuse and modulation of immune function: consequences in the susceptibility to opportunistic infections. J Neuroimmune Pharmacol. 2011;6(4):442-65.

186. Miller M, Sturmer T, Azrael D, Levin R, Solomon DH. Opioid analgesics and the risk of fractures in older adults with arthritis. J Am Geriatr Soc. 2011;59(3):430-8.

187. Solomon DH, Rassen JA, Glynn RJ, Lee J, Levin R, Schneeweiss $\mathrm{S}$. The comparative safety of analgesics in older adults with arthritis. Arch Intern Med. 2010;170(22):1968-76.

188. Justice AC, Freiberg MS, Tracy R, Kuller L, Tate JP, Goetz MB, et al. Does an index composed of clinical data reflect effects of inflammation, coagulation, and monocyte activation on mortality among those aging with HIV? Clin Infect Dis. 2012;54(7): 984-94.

189. Justice AC, McGinnis KA, Skanderson M, Chang CC, Gibert CL, Goetz MB, et al. Towards a combined prognostic index for survival in HIV infection: the role of 'non-HIV' biomarkers. HIV Med. 2010;11(2):143-51.
190. Altice FL, Bruce RD, Lucas GM, Lum PJ, Korthuis PT, Flanigan TP, et al. HIV treatment outcomes among HIV-infected, opioid-dependent patients receiving buprenorphine/naloxone treatment within HIV clinical care settings: results from a multisite study. J Acquir Immune Defic Syndr. 2011;56(Suppl 1):S22-32.

191. Fiellin DA, Weiss L, Botsko M, Egan JE, Altice FL, Bazerman LB, et al. Drug treatment outcomes among HIV-infected opioiddependent patients receiving buprenorphine/naloxone. J Acquir Immune Defic Syndr. 2011;56(Suppl 1):S33-8.

192. Gedmintas L, Solomon DH. HIV and its effects on bone: a primer for rheumatologists. Curr Opin Rheumatol. 2012;24(5): 567-75.

193. Hughes AK. HIV knowledge and attitudes among providers in aging: results from a national survey. AIDS Patient Care STDS. 2011;25(9):539-45.

194. Nkansah N, Mostovetsky O, Yu C, Chheng T, Beney J, Bond Christine $\mathrm{M}$, et al. Effect of outpatient pharmacists' non-dispensing roles on patient outcomes and prescribing patterns. Cochrane Database Syst Rev. 2010;(7):CD000336. http://www. mrw.interscience.wiley.com/cochrane/clsysrev/articles/CD0003 36/frame.html. 